\title{
KARAKTERISTIK FISIKOKIMIA DAN SENSORIS FRUIT LEATHER APEL MANALAGI (MALUS SYLVESTRIS MILL) DENGAN SUBTITUSI PISANG CANDI (MUSA PARADISIACA)
}

\section{Physicochemical Characteristics and Sensory of Fruit Leather Apple Manalagi (Malus sylvestris mill) With The Substitution of Banana Spain (Musa paradisiaca)}

\author{
Lilianti Puspaningrum*, Sudarminto S. Yuwono, Erryana Martati \\ Jurusan Teknologi Hasil Pertanian - Fakultas Teknologi Pertanian - Universitas Brawijaya \\ Jalan Veteran - Malang 65145 \\ *Penulis Korespondensi: email lianpuspa@gmail.com
}

Disubmit: 22 Mei 2018 Direvisi: 19 Agustus 2018 Diterima: 21 Desember 2018

\begin{abstract}
ABSTRAK
Fruit Leather merupakan salah satu olahan yang berbahan dasar buah-buahan yang dihaluskan (bubur buah) dengan cara mengurangi kadar air dari produk tersebut. Tujuan dari penelitian ini adalah mengetahui karakteristik penambahan komposisi pisang candi dalam pembuatan fruit leather apel manalagi sehingga mendapatkan produk fruit leather yang baik yang dapat diterima konsumen. Fruit Leather apel dibuat dengan menggunakan Rancangan Acak Lengkap (RAL) dengan 4 perlakuan komposisi apel:pisang (100\% apel, 85\% apel : 15\% pisang, $70 \%$ apel:30\% pisang dan 55\% apel:45\% pisang). Analisa sensori dilakukan dengan menggunakan metode Rate All That Apply (RATA). Hasil analisa menunjukkan bahwa nilai kekerasan (hardness), kekompakan (cohesivenes), kelengketan (adhesiveness) dan elastisitas (springiness) penambahan pisang candi terbaik pada komposisi pembuatan fruit leather apel $70 \%$ apel:30\% pisang dengan atribut sensoris rasa manis, aroma pisang, tekstur keras dan tekstur elastis
\end{abstract}

Kata kunci: Apel; Fruit Leather; Pisang; Karakteristik Sensori Tekstur

ABSTRACT

Fruit Leather is one of the processed based fruits that are smoothed (fruit pulp) by reducing the water content of the product. The purpose of this study was to determine characteristics of the addition of banana in making fruit leather apple manalagi so get good fruit leather product acceptable to consumer. Fruit Leather apple was made using a completely randomized design with 4 treatments of apple composition : bananas (100\% apples, $85 \%$ apples: $15 \%$ bananas, $70 \%$ apples: $30 \%$ bananas and $55 \%$ apples: $45 \%$ bananas). Sensory analysis was performed using the Rate All That Apply (RATA) method. The results of the analysis show that Hardness, Cohesiveness, Adhesiveness and Elasticity addition of the best temple banana on the composition of apple fruit apple making $70 \%$ apple: $30 \%$ banana with sensory attribute of sweet taste, banana aroma, hard textures and elastic textures

Keywords: Apple; Banana; Fruit leather; Texture; Sensory Characteristics 
Jurnal Teknologi Pertanian Vol. 19 No. 3 [Desember 2018] 173-182

Fisikokimia dan Sensoris Fruit Leather Apel Manalagi [Puspaningrum dkk]

\section{PENDAHULUAN}

Fruit leather apel merupakan struktur produk makanan yang dibuat dengan pengurangan kadar air pada bubur buah (puree) sehingga menjadi lembaran tipis yang fleksibel (Valenzuela dan Aguilera, 2015). Fruit leather berbentuk lembaran tipis dengan ketebalan 2-3 mm, kadar air 10-15\%, mempunyai konsistensi dan rasa khas sesuai dengan jenis buah-buahan yang digunakan (Historiasih, 2010). Meski fruit leather apel mudah dan sederhana, tetapi memiliki kelemahan bila tidak ada penambahan bahan lain sehingga kualitas serta warna yang dihasilkan kurang menarik sehingga dibutuhkan kombinasi beberapa buah untuk menambah kualitas serta nilai kandungan nutrisi didalamnya (Leiva Díaz et al., 2009; Valenzuela dan Aguilera, 2015). Beberapa penelitian telah dilakukan dalam mengkombinasikan buah-buahan dalam pembuatan fruit leather seperti apel dan kiwi (Torres et al., 2015), dan penggunaan pisang sebagai fruit leather pisang tanduk (Fauziah et al., 2015). Disisi lain, Diamante et al. (2014) juga menyatakan, belum ditemukannya bahan yang dapat ditambahkan pada apel leather untuk melindungi warna dan meningkatkan kualitasnya. Penelitian yang ditulis oleh Diamante et al. (2014) meneliti fruit leather dari buah apel-blackcurrant untuk meningkatkan fisiko-kimia dan sensoris dari leather tersebut. Hasil penelitiannya menunjukkan bahwa campuran blackcurrant dapat meningkatkan sifat fisiko-kimia dan sensoris dari apple-blackcurrant leather, tetapi memerlukan pengurangan waktu pemanasan dalam pembuatan leather tersebut. Penelitian tersebut menunjukkan bahwa perlu adanya penambahan buah lain untuk meningkatkan sifat fisiko-kimia dan sensoris dari apel leather.

Pada buah pisang candi terkandung karbohidrat, protein, kalsium, fosfor, besi, vitamin A, B, dan vitamin C. Kandungan pisang yang baik bagi tubuh serta tekstur pisang yang lembut diharapkan dapat memperbaiki tekstur fruit leather apel menjadi lebih baik. Metode Rate All that Apply (RATA) merupakan suatu metode kuantitatif dalam melakukan sensory profiling yang bertujuan untuk mengetahui persepsi konsumen dalam menentukan karakteristik suatu produk. Melalui karakteristik tersebut dapat diketahui perbedaan antara sampel yang diujikan secara objektif (Ares et al., 2014). Berdasar- kan hal itu, tujuan penelitian ini adalah penganekaragaman produk dari buah apel dan pisang serta suhu pengeringan tertentu untuk menghasilkan fruit leather yang berkualitas yang dapat diterima oleh masyarakat.

\section{METODE}

Bahan yang digunakan pada penelitian ini meliputi apel manalagi yang diperoleh dari petani apel di Malang. Pisang candi dari pasar Belimbing di Malang, dan gula pasir yang diperoleh di Minimarket (Indomaret). Bahan yang digunakan untuk analisa fruit leather adalah $\mathrm{HCl} 0.1 \mathrm{~N}, \mathrm{HCl} 25 \%$, etanol $95 \%$, aquadest, $\mathrm{NaOH} 45 \%$, Nelson A dan B, arsenomolibdat.

Alat yang digunakan pada penelitian ini adalah termometer, shaker, pendingin balik (refluks), cabinet dryer, spektrofotometer Vis merek 20 D Plus, Texture Profile Analyzer (TPA) merek CT-3 Texture Analyzer (AMETEK Brookfield, Middleboro, USA), loyang aluminium dengan ukuran $28 \times 22.5 \times 2 \mathrm{~cm}$, timbangan analitik merek Mettler Toledo tipe Newclassic MF, desikator (SIMAX), vortex (Turbo Mixer), oven, waterbath, mixer, blender, timbangan analitik (Scoutpro), crusch porselin, corong, timbangan digital, dan glassware.

Tahap pertama pembuatan fruit leather dilakukan menggunakan rancangan percobaan Rancangan Acak Lengkap (RAL) yang terdiri dari 4 perlakuan yaitu F1 $=100 \%$ apel manalagi; F2 $=85 \%$ apel manalagi : $15 \%$ pisang candi; F3 $=70 \%$ apel manalagi : $30 \%$ pisang candi dan $\mathrm{F} 4=55 \%$ apel manalagi : $45 \%$ pisang candi. Tahap kedua adalah analisa sensori dengan menggunakan metode Rate All that Apply (RATA).

Pada proses pembuatan fruit leather, buah apel dan pisang dikupas dan dicuci kemudian ditimbang sesuai dengan komposisi yaitu $100 \%$ apel, $85 \%$ apel : $15 \%$ pisang, $70 \%$ apel : $30 \%$ pisang dan $55 \%$ apel : $45 \%$ pisang. Buah tersebut dilakukan blanching dengan suhu $80^{\circ} \mathrm{C}$ selama 5 menit. Pada buah yang telah di blanching, diblender hingga menjadi bubur buah. Bubur buah dicetak pada cetakan berukuran $28 \times 22.5 \times 2 \mathrm{~cm}$ untuk $250 \mathrm{~g}$. Masukkan ke oven dengan suhu $60-62^{\circ} \mathrm{C}$ kemudian dipanaskan selama \pm 8 jam (modifikasi Offia-Olua dan Ekwunife, 2015). 
Pada analisa kadar air, sampel ditimbang sebanyak 0.59-3.17 g dalam cawan petri yang telah diketahui beratnya. Sampel dikeringkan dalam oven pada suhu $105^{\circ} \mathrm{C}$ selama 5 jam. Dinginkan dalam desikator dan ditimbang, perlakuan diulang hingga tercapai berat konstan selama 48 jam. Analisa yang digunakan berdasarkan teknik analisa AOAC (AOAC, 2005).

Analisa kadar pati berdasarkan Sudarmadji et al. (2010). Sebanyak 2-5 g sampel fruit leather ditimbang dalam erlenmenyer $250 \mathrm{ml}$. Tambahkan $50 \mathrm{ml}$ aquadest dan dibiarkan selama 1 jam sambil kadang-kadang dikocok. Suspensi disaring dengan kertas saring Whatman nomer 40 dan dicuci dengan aquadest sampai volume filtrat $250 \mathrm{ml}$ ke dalam erlenmenyer $250 \mathrm{ml}$. Pati yang terdapat sebagai residu pada kertas saring dicuci sampai 5 kali dengan $10 \mathrm{ml}$ eter kemudian cuci kembali dengan $150 \mathrm{ml}$ alkohol $10 \%$. Residu dipindah secara kuantitatif dari kertas saring ke dalam erlenmenyer dengan cara pencucian dengan $200 \mathrm{ml}$ aquadest dan ditambah $20 \mathrm{ml} \mathrm{HCl} \mathrm{25 \% ,} \mathrm{kemudian} \mathrm{ditu-}$ tup dengan pendingin balik dan selama 2.5 jam. Setelah dingin, dinetralkan dengan larutan $\mathrm{NaOH} 45 \%$ dan diencerkan sampai volume 500 $\mathrm{ml}$ ke dalam labu takar $500 \mathrm{ml}$, kemudian diukur absorbansinya menggunakan spektrofotometer vis dengan panjang gelombang $540 \mathrm{~nm}$.

Pada analisa kadar pektin, bubur fruit leather ditimbang sebanyak $50 \mathrm{~g}$ dan dimasukkan ke dalam labu ukur $250 \mathrm{ml}$. $\mathrm{HCl} 0.1$ $\mathrm{N}$ ditambahkan hingga $\mathrm{pH}$ mencapai nilai 1.5. Selanjutnya, diekstraksi dengan suhu 65 ${ }^{\circ} \mathrm{C}$ selama 1 jam pada waterbath shaker. Larutan disaring dengan kain saring. Endapan dimasukkan ke dalam beaker glass. Etanol $\left(\mathrm{C}_{2} \mathrm{H}_{5} \mathrm{OH}\right)$ 95\% dan $2 \mathrm{ml} \mathrm{HCl}$ pekat ditambahkan per 1 liter etanol dengan perbandingan filtrat dan etanol 1:1.5. Diendapkan selama 12 jam kemudian disaring dengan kain saring. Endapan dicuci dengan etanol 95\% hingga bebas klorida. Hasil endapan yang telah bersih dikeringkan pada suhu $40^{\circ} \mathrm{C}$ selama 8 jam hingga berat konstan (Modifikasi Ismail et al., 2012).

Pada analisa texture profile analysis (TPA), sampel dianalisa dengan menggunakan Texture Profile Analyzer (TPA) merek CT-3 Texture Analyzer (AMETEK Brookfield, Middleboro, USA) dengan analisa software TexturePro CT. Analisa tekstur fruit leather apel meliputi kekerasan, kekompakan, kelengketan dan elastisitas. Probe yang digunakan adalah TA44 untuk 2 siklus compression test dengan load cell $1000 \mathrm{~g}$. Bentuk sampel fruit leather apel yang dianalisa adalah lembaran tipis ukuran panjang $30 \mathrm{~mm}$, lebar $20 \mathrm{~mm}$ dan tinggi 2-3 $\mathrm{mm}$. Kondisi metode pengujian yang dilaksanakan adalah pre-test speed $2 \mathrm{~mm} / \mathrm{s}$, test speed $10 \mathrm{~mm} / \mathrm{s}$, return speed $10 \mathrm{~mm} / \mathrm{s}$, recovery time $0 \mathrm{~s}$, hold time $0 \mathrm{~s}$, dan trigger load $6.8 \mathrm{~g}$.

Analisa sensori menggunakan metode RATA dengan melibatkan panelis konsumen sebagai sumber untuk mengevaluasi intensitas atribut pada keempat sampel. Uji sensoris menggunakan 110 panelis yang dipilih secara acak. Data hasil pengamatan dianalisis dengan menggunakan Microsoft Excel 2010 dan Minitab 16. Data hasil pengamatan dianalisa dengan menggunakan ANOVA berupa Generalized Linear Model (GLM). Apabila terdapat pengaruh interaksi perlakuan yang signifikan dilanjutkan dengan menggunakan uji lanjut Tukey Test dengan taraf kepercayaan 95\% (P $\leq$ 0.05). Perlakuan terbaik ditentukan dengan menggunakan metode Zeleny (1982).

\section{HASIL DAN PEMBAHASAN}

\section{Kadar Air (\% bb)}

Kadar air erat kaitannya dengan keawetan pangan. Jika kadar air rendah dapat memperpanjang umur simpan dari suatu produk. Pada Tabel 1 menunjukkan bahwa semakin banyak penambahan pisang candi, kadar air fruit leather mengalami penurunan. Hal ini dipengaruhi oleh komposisi kadar air bahan baku dimana pisang memiliki kadar air lebih rendah daripada apel yaitu $64.01 \%$, sedangkan kadar air apel sebesar 81.21\%. Komposisi kimia bahan baku dapat mempengaruhi komposisi kimia pada produk akhir. Pada produk fruit leather kombinasi buah terjadi penurunan kadar air bahan seiring dengan bertambahnya bahan baku (memiliki kadar air lebih rendah) yang ditambahkan pada komposisi pembuatan fruit leather (Ramadhan et al., 2015; Risti dan Herawati, 2017). Pada penambahan komposisi pisang $45 \%$, terjadi kenaikan kadar air fruit leather. Hal ini dikarenakan penambahan pisang candi mampu menaikkan kadar pati bahan yang dapat mempengaruhi kadar air fruit leather. Saat pemanasan pati akan terjadi gelatinisasi yang mengakibatkan penyerapan air dalam bahan. 
Molekul-molekul amilosa dan amilopektin secara fisik hanya dipertahankan oleh adanya ikatan hidrogen lemah. Atom hidrogen dari gugus hidroksil akan tertarik pada muatan negatif atom oksigen dari gugus hidroksil yang lain. Bila suhu suspensi naik, maka ikatan hidrogen makin lemah, sedangkan energi kinetik molekul-molekul air meningkat, memperlemah ikatan hidrogen antar molekul air (Widjanarko, 2018). Selain itu, pembuatan fruit leather adalah bentuk pencampuran dari berbagai macam buah, gula dan asam sehingga peningkatan kadar air.

\section{Kadar Pektin (\%)}

Pektin merupakan suatu struktur yang heterogen yang sebagian besar terdiri atas asam-asam poligalakturonat. Tabel 1 menunjukkan bahwa semakin banyak penambahan pisang, kadar pektin semakin meningkat hal ini dikarenakan hasil uji bahan baku menunjukkan kadar pektin pisang sendiri memiliki nilai lebih tinggi yaitu sebesar $0.978 \%$, sedangkan kadar pektin pada apel sebesar $0.636 \%$, sehingga saat penambahan komposisi pisang dalam produk dapat menaikkan nilai kadar pektin pada produk fruit leather apel.

Pada penelitian Sa'adah dan Estiasih (2015) mengungkapkan bahwa kandungan pektin dalam buah apel sebesar $0.57 \%$, sedangkan pada penelitian Erawati (2009), kandungan pektin yang terdapat pada pisang sebesar $0.95 \%$. Banyaknya bahan baku yang ditambahkan akan mempengaruhi komposisi kimia pada produk akhir hal ini terbukti dengan meningkatnya kadar pektin seiring dengan penambahan pisang candi pada pembuatan fruit leather apel. Matriks buah terutama terdiri dari karbohidrat seperti gula, pektin dan zat selulosa (Torley et al., 2008). Sel-sel tertentu seperti buah cenderung mengumpulkan lebih banyak pektin. Pektin banyak terkandung pada kulit buah jeruk, apel dan lain-lain (Hastuti, 2016).

\section{Kadar Pati (\%)}

Pada Tabel 1 menunjukkan terjadi kenaikan kadar pati pada produk seiring bertambahnya komposisi pisang candi dalam produk. Hal ini karena kadar pati pisang sendiri memiliki nilai lebih tinggi daripada kadar pati pada apel, sehingga saat penambahan komposisi pisang dalam produk dapat menaikkan nilai kadar pati pada produk fruit leather apel. Hasil analisa bahan baku menunjukkan kadar pati apel sebesar $1.51 \%$, sedangkan kandungan pati pada pisang candi sebesar 6.07\%. Data pada USDA (2017) menunjukkan bahwa kandungan pati yang terkandung pada pisang sebesar $5.38 \%$. Pati adalah polisakarida dengan polimer dari a D-glukosa, secara alami berada dalam jaringan tanaman termasuk akar-akaran, umbiumbian, sayuran hijau dan buah (Amani $e t$ al., 2007).

\section{Kekerasan (Hardness)}

Kekerasan (hardness) merupakan besarnya gaya yang diberikan hingga terjadi perubahan bentuk (deformasi) pada sampel. Pada Tabel 2 menunjukkan adanya kenaikan tingkat kekerasan (hardness) pada fruit leather apel seiring dengan penambahan pisang candi hingga 30\%. Peningkatan kekerasan pada produk saat penambahan komposisi pisang disebabkan oleh kadar air pada bahan. Penurunan kadar air dapat meningkatkan nilai kekerasan pada fruit leather apel. Pemanasan akan menyebabkan antar molekul-molekul $\mathrm{H}_{2} \mathrm{O}$ terputus sehingga molekul-molekul $\mathrm{H}_{2} \mathrm{O}$ bergerak demikian cepat dan beberapa molekul dapat melarikan diri dari permukaan dan menjadi gas (Winarno, 2008).

Kehilangan air dalam bahan akan membuat ikatan antar matrik bahan semakin erat sehingga mempengaruhi tekstur kekerasan (hardness) pada produk. Hal ini didukung oleh penyataan Nurminah et al. (2016) bahwa peningkatan nilai kekerasan gel ada pada bertambahnya pektin disebabkan karena pektin bersama gula dan asam membentuk gel yang kuat sehingga dapat membuat kekerasan gel pada produk semakin keras. Terjadi penurunan tingkat kekerasan pada penambahan pisang candi $45 \%$, hal ini dikarenakan peningkatan kadar air bahan yang dipengaruhi oleh peningkatan kadar pati. Saat pemanasan, pati pada bahan akan terjadi gelatinisasi sehingga menyerap air. Menurut Asgar danMusaddad (2006), peningkatan daya serap air dipengaruhi oleh adanya pati yang telah tergelatinisasi selama proses pengeringan. Panas yang diberikan selama gelatinisasi sekitar $50-70{ }^{\circ} \mathrm{C}$ mengakibatkan pembengkakan energi kinetik molekul air yang tarik menarik dengan molekul pati dalam granula. Anggraini (2016) menambahkan bahwa perbedaan tingkat kekesaran dan tekstur pada fruit leather dipengaruhi oleh pembentukan gel yang disebabkan oleh pektin, serat, dan pati yang berpengaruh terhadap gelatinasi 
pada waktu pemanasan yang memberikan hasil berupa matrik gel, sehingga fruit leather memiliki tekstur yang baik. Korelasi antara kadar air dan tingkat kekerasan dapat dilihat pada Gambar 1. Pada Gambar 1, nilai koefisien determinasi yang diperoleh menunjukkan bahwa tinggi rendahnya nilai kadar air $(\% \mathrm{bb})$ pada fruit leather akan mempengaruhi nilai tingkat kekerasan (g), fruit leather sebesar $95.04 \%$.

\section{Kekompakan (Cohesiveness)}

Pada Tabel 2 menunjukkan bahwa penambahan pisang candi hingga $30 \%$ pada produk memberikan peningkatan nilai kekompakan (cohesiveness) produk fruit leather apel, sedangkan pada penambahan pisang hingga $45 \%$ terjadi penurunan tingkat kekompakan dari produk. Hal ini diduga karena pengeringan mampu membuat jaringan pada matriks bahan menjadi padat (terikat antar jaringan) sehingga menaikkan kekompakan fruit leather. Aguilera (2003) mengemukakan bahwa pada tingkat pengeringan rendah produk akhir, akan menyebabkan lebih kompak dan lebih padat karena molekul terbentuk jaringan matriks pada fruit leather yang dapat menyebabkan penurunan kepadatan matriks. Kekompakan menunjukkan kekuatan internal yang membentuk suatu bahan pangan atau menunjukkan hubungan antara kekuatan atau kekompakan bahan yang saling berinteraksi. Semakin tinggi nilai yang diperoleh menunjukkan bahwa semakin padu atau kompak produk tersebut (Azhar et al., 2018). Pada penambahan pisang hingga $45 \%$ selain terjadi gelatinisasi yang mengakibatkan masuknya air pada jaringan bahan sehingga melunakkan jaringan, peningkatan total gula pada fruit leather selain untuk pemanis juga untuk pembentuk tekstur, ketika terdapat pektin di dalam sebuah campuran air, gula akan mempengaruhi keseimbangan pektin dan air karena gula berfungsi sebagai dehydrating agent yang mengurangi air di permukaaan pektin yang mengakibatkan kemampuan mengikar air semakin meningkat (Gardjito dan Sari, 2005; Zulkipli, 2016).

\section{Kelengketan (Adhesiveness)}

Kelengketan merupakan tenaga yang diperlukan untuk menghilangkan gaya tarik-menarik antara permukaan bahan makanan dan permukaan bahan lain ketika terjadi kontak (lidah, langit-langit, dan gigi) selama proses memakan (Cardarelli et al.,
2008). Pada Tabel 2 memperlihatkan bahwa semakin tinggi penambahan pisang, maka nilai kelengketan fruit leather apel semakin menurun. Hal ini diduga dipengaruhi oleh kadar air fruit leather apel. Terjadi penurunan kadar air fruit leather apel seiring dengan bertambahnya komposisi pisang yang diberikan pada produk. Kadar air sangat mempengaruhi tekstur dalam bahan pangan. Pemanasan akan menyebabkan antar molekul-molekul $\mathrm{H}_{2} \mathrm{O}$ terputus sehingga molekul-molekul $\mathrm{H}_{2} \mathrm{O}$ bergerak demikian cepat dan beberapa molekul dapat melarikan diri dari permukaan dan menjadi gas (Winarno, 2008). Menguapnya air ini mengakibatkan berkurangnya kandungan air pada fruit leather apel. Perpindahan air sebagian dari matriks bahan menyebabkan berkurangnya kerapatan dan menyebabkan kelengketan berkurang (Sinurat dan Murniyati, 2014). Selain itu, penambahan pisang menurunkan kadar air produk yang berakibat tegangan permukaan air, padatan dan interaksi air mengalami penurunan.

\section{Elastisitas (Springiness)}

Pada Tabel 2 terlihat bahwa penambahan komposisi pisang candi menurunkan nilai elastisitas (springiness) produk. Penurunan elastisitas bahan diduga berhubungan dengan kandungan kadar air fruit leather apel yang menurun menyebabkan penurunan tingkat elastisitas fruit leather apel. Terjadi penurunan kadar air pada produk fruit leather apel seiring dengan bertambahnya penambahan pisang candi. Hal ini didukung oleh penelitian Rahmanto et al. (2014), pada penelitian fruit leather nangka, semakin kecil kadar air fruit leather maka tekstur fruit leather akan semakin keras dan tidak elastis. Air berfungsi sebagai bahan yang dapat mendispersikan berbagai senyawa yang ada dalam bahan makanan. Peningkatan nilai kekerasan gel juga dipengaruhi oleh peningkatan kadar pektin disebabkan karena pektin bersama gula dan asam membentuk gel yang kuat sehingga dapat membuat kekerasan gel pada produk semakin keras sehingga (Nurminah et al., 2016).

\section{Kuat Tarik (Tensile Strength)}

Pada analisa kuat tarik semakin besar komposisi penambahan pisang candi dalam pembuatan fruit leather apel, semakin meningkat nilai kuat tarik produk, hal ini terlihat pada Tabel 2. Penurunan kadar air 
Jurnal Teknologi Pertanian Vol. 19 No. 3 [Desember 2018] 173-182

Fisikokimia dan Sensoris Fruit Leather Apel Manalagi [Puspaningrum dkk]

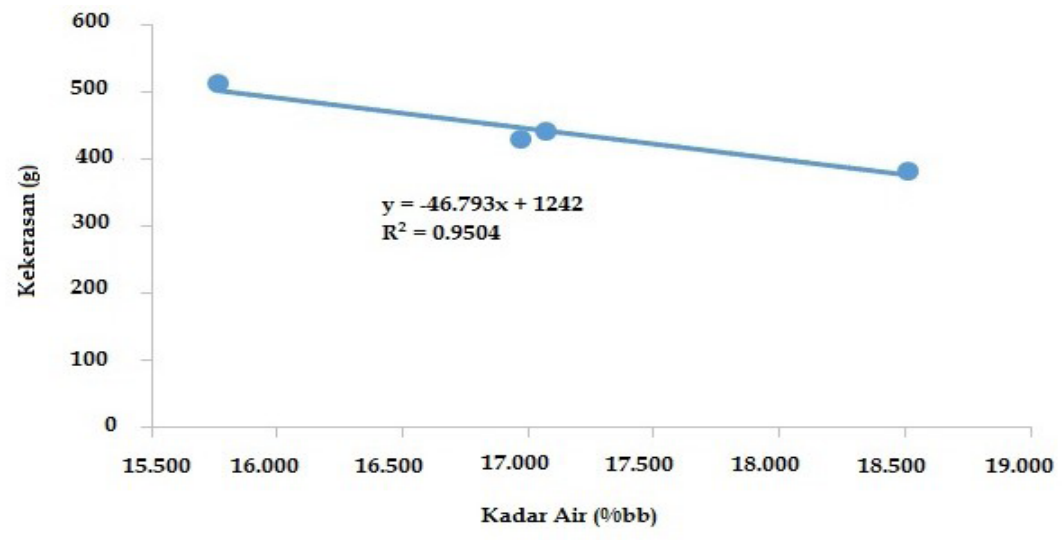

Gambar 1. Grafik korelasi antara kadar air (\% bb) dan tingkat kekerasan (g) subtitusi pisang candi pada fruit leather apel

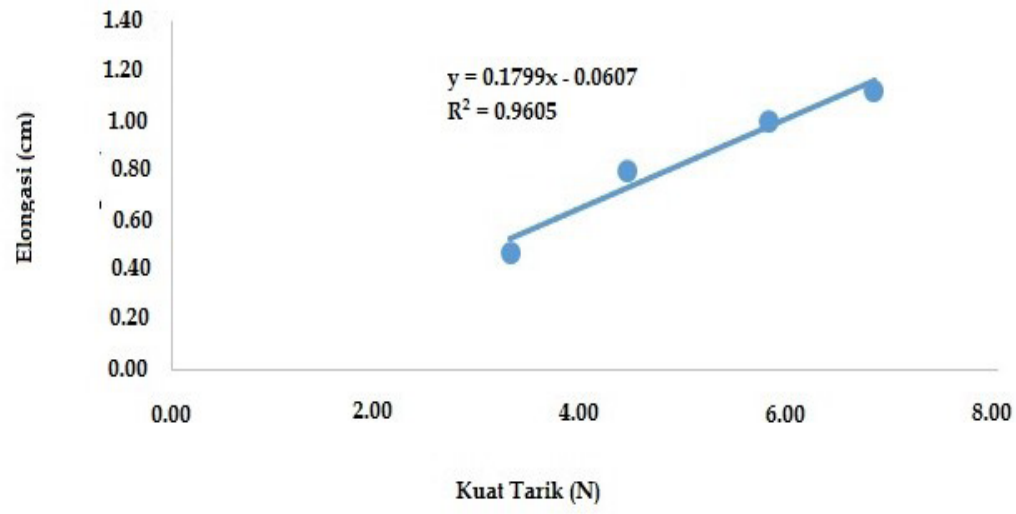

Gambar 2. Grafik korelasi antara kuat tarik (N) dan perpanjangan (elongasi) $(\mathrm{cm})$ subtitusi pisang candi pada fruit leather apel

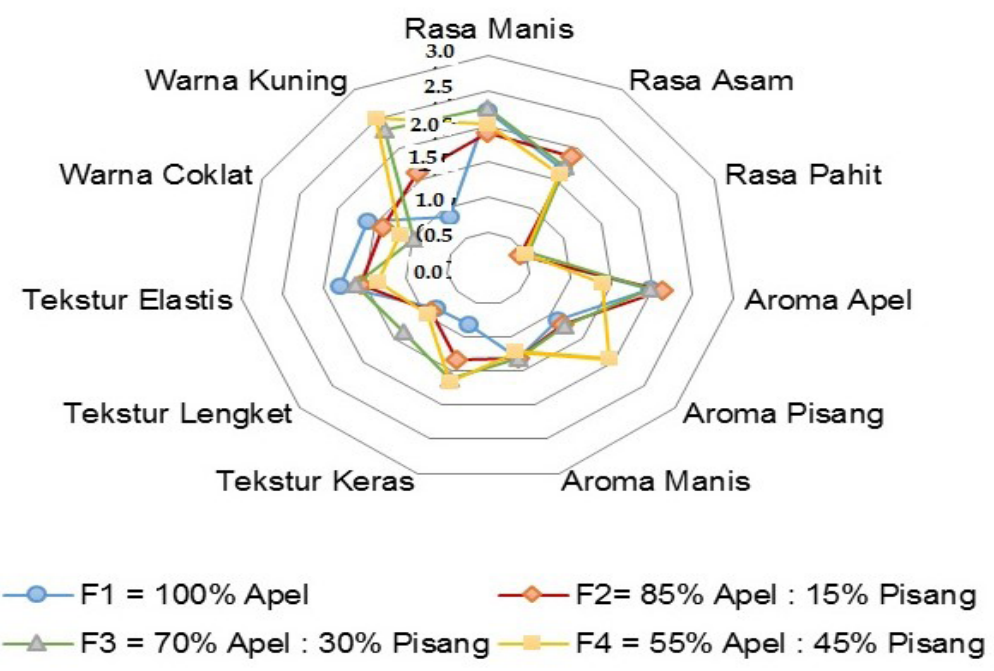

Gambar 3. Spinder chart atribut sensoris keempat fruit leather 
terjadi hingga komposisi penambahan pisang $30 \%$ pisang. Penurunan kadar air ini diduga menyebabkan ikatan matriks pada bahan semakin erat dan kokoh, sehingga akan menaikkan nilai kuat tarik pada bahan. Kekuatan tarik dapat timbul akibat adanya ikatan polimer yang terjadi atar atom atau ikatan sekunder dengan rantai polimer oleh gaya yang diberikan dari luar (Amaliya dan Putri, 2014). Meskipun pada penambahan pisang $45 \%$ menaikkan kadar air bahan, tetapi tidak diikuti penurunan nilai kuat tarik bahan. Pada penambahan pisang $45 \%$ terjadi gelatinisasi yang menyebabkan masuknya air pada bahan. Saat pemanasan akan terjadi tarik menarik antara molekul air dan molekul pati.

Menurut Asgar dan Musaddad (2006), peningkatan daya serap air dipengaruhi oleh adanya pati yang telah tergelatinisasi selama proses pengeringan. Oleh sebab itu, nilai kuat tarik tidak menurun seiring dengan kenaikan kadar air pada penambahan pisang $45 \%$. Pada penelitian yang dilakukan Widyaningsih et al. (2012) penambahan konsentrasi pektin akan meningkatkan nilai kuat tarik edible film, karena pektin mampu membentuk matriks polimer yang kuat dan menjadikan kuat tarik intermolekul semakin kuat.

\section{Perpanjangan (Elongasi)}

Perpanjangan (elongasi) merupakan persentase perpanjangan atau kemampuan maksimal fruit leather saat mulai sobek. Menurut Bertuzzi et al. (2012), Hasil analisa menunjukkan bahwa penambahan pisang candi dalam komposisi pembuatan fruit leather apel memberikan pengaruh nyata ( $p$-val$u e<0.05$ ) terhadap nilai perpanjangan (elongasi) dari produk. Terlihat bahwa semakin besar komposisi penambahan pisang candi dalam pembuatan fruit leather apel, semakin

Tabel 1. Karakteristik kimia fruit leather apel dengan penambahan pisang candi

\begin{tabular}{cccc}
\hline \multirow{2}{*}{ Perlakuan } & \multicolumn{3}{c}{ Karakteristik Kimia } \\
\cline { 2 - 4 } & Kadar Air (\% bb) & Kadar Pektin (\%) & Kadar Pati (\%) \\
\hline Apel 100\% & $18.51^{\mathrm{a}}$ & $3.27^{\mathrm{a}}$ & $5.60^{\mathrm{a}}$ \\
85\% Apel : 15\% Pisang & $16.97^{\mathrm{b}}$ & $3.86^{\mathrm{ab}}$ & $6.19^{\mathrm{b}}$ \\
$70 \%$ Apel : 30\% Pisang & $15.76^{\mathrm{c}}$ & $4.60^{\mathrm{bc}}$ & $7.33^{\mathrm{c}}$ \\
$55 \%$ Apel : 45\% Pisang & $17.07^{\mathrm{b}}$ & $5.04^{\mathrm{c}}$ & $9.1^{8} \mathrm{~d}$ \\
\hline
\end{tabular}

Tabel 2. Karakteristik fisik fruit leather apel dengan penambahan pisang candi

\begin{tabular}{ccccccc}
\hline & \multicolumn{5}{c}{ Karakteristik Fisik } \\
\cline { 2 - 7 } Perlakuan & $\begin{array}{c}\text { Kekerasan } \\
(\mathbf{g})\end{array}$ & $\begin{array}{c}\text { Kekom- } \\
\text { pakan }\end{array}$ & $\begin{array}{c}\text { Kelengketan } \\
(\mathbf{m J})\end{array}$ & $\begin{array}{c}\text { Elastisi- } \\
\text { tas } \\
(\mathbf{m m})\end{array}$ & $\begin{array}{c}\text { Kuat } \\
\text { Tarik } \\
(\mathbf{N})\end{array}$ & $\begin{array}{c}\text { Elongasi } \\
(\mathbf{c m})\end{array}$ \\
\hline Apel 100\% & $383.58^{\mathrm{b}}$ & $1.02^{\mathrm{c}}$ & $1.03^{\mathrm{a}}$ & $4.21^{\mathrm{a}}$ & $3.28^{\mathrm{c}}$ & $0.48^{\mathrm{c}}$ \\
$85 \%$ Apel : 15\% Pisang & $431.48^{\mathrm{b}}$ & $1.48^{\mathrm{b}}$ & $0.52^{\mathrm{ab}}$ & $3.38^{\mathrm{ab}}$ & $4.40^{\mathrm{bc}}$ & $0.80^{\mathrm{b}}$ \\
$70 \%$ Apel : 30\% Pisang & $514.33^{\mathrm{a}}$ & $1.74^{\mathrm{a}}$ & $0.27^{\mathrm{ab}}$ & $2.42^{\mathrm{b}}$ & $5.78^{\mathrm{ab}}$ & $1.00^{\mathrm{ab}}$ \\
$55 \%$ Apel : 45\% Pisang & $441.88^{\mathrm{b}}$ & $1.46^{\mathrm{b}}$ & $0.10^{\mathrm{b}}$ & $3.60^{\mathrm{ab}}$ & $6.80^{\mathrm{a}}$ & $1.1^{3} \mathrm{a}$ \\
\hline
\end{tabular}

Tabel 3. Penentuan perlakuan terpilih

\begin{tabular}{cccccc}
\hline $\begin{array}{c}\text { Formulasi Fruit Leather } \\
\text { (Apel : Pisang) }\end{array}$ & L1 & L2 & Lmax & Total & Rangking \\
\hline 100\% Apel & 0.7981 & 0.2009 & 0.0032 & 1.0022 & 3 \\
85\% Apel : 15\% Pisang & 0.8336 & 0.1664 & 0.0016 & 1.0016 & 2 \\
70\% Apel : 30\% Pisang & 0.8725 & 0.1189 & 0.0026 & 0.9940 & 1 \\
55\% Apel : 45\% Pisang & 0.8102 & 0.1898 & 0.0026 & 10026 & 4 \\
\hline
\end{tabular}


meningkatkan nilai perpanjangan (elongasi). Nilai elongasi dipengaruhi oleh nilai kuat tarik produk fruit leather. Semakin kompak jaringan pada suatu produk, ikatan heliks yang terjadi semakin kompak sehingga menaikkan nilai kuat tarik dan mempengaruhi peningkatan perpanjangan (elongasi). Hal ini sesuai dengan pernyataan Tethool (2011) bahwa semakin tinggi nilai kuat tarik (tensile strength), sifat semakin kompak sehingga perpanjangan (elongasi) mengalami kenaikan. Aguilera (2003) mengemukakan bahwa pada tingkat pengeringan rendah produk akhir, akan menyebabkan lebih kompak dan lebih padat karena molekul terbentuk jaringan matriks pada fruit leather yang dapat menyebabkan kepadatan matriks. Konsentrasi pektin dan pati menyebabkan peningkatan nilai persen elongasi (Pradana et al., 2017). Hal ini karena pektin dan pati bersifat hidrofilik yang akhirnya membentuk ruang bebas dan meningkatkan mobilitas molekul membentuk ikatan hidrogen.

Pada Gambar 3 menunjukkan bahwa perlakuan penambahan pisang candi pada pembuatan fruit leather dengan 4 perlakuan dievaluasi memiliki 11 atribut sensoris seperti rasa manis, rasa asam, rasa pahit, aroma apel, aroma pisang, aroma manis, tekstur keras, tekstur lengket, tekstur elastis, warna coklat, dan warna kuning. Atribut ini dinilai panelis sesuai dengan yang dideteksi pada keempat sampel fruit leather. Penambahan pisang candi dalam pembuatan fruit leather apel dengan komposisi $70 \%$ apel dan 30\% pisang candi memiliki nilai tertinggi pada atribut sensoris rasa manis, aroma pisang, tekstur keras dan tekstur elastis, serta warna kuning, sedangkan rasa pahit dan aroma manis terjadi penurunan. Penambahan pisang candi dalam pembuatan fruit leather tidak berpengaruh terhadap rasa pahit dan aroma manis pada keempat hal ini dikarenakan pada perlakuan tersebut panelis tidak dapat mendeteksi intensitas terhadap kedua atribut tersebut.

\section{Perlakuan Terbaik}

Penentuan perlakuan terbaik menggunakan multiple atribute (Zeleny, 1982) adalah dengan menentukan nilai ideal pada masing-masing parameter. Penentuan perlakuan terbaik dianalisa dari parameter kimia, fisik, dan organoleptik (Kurniasari dan Murtini, 2017). Parameter yang digunakan meliputi fisik, kimia dan sensoris terhadap fruit leather apel yaitu Uji Tekstur Profile Analysis (TPA), kuat tarik, elongasi, kadar air, kadar pektin dan kadar pati serta 11 atribut sensoris pada produk.

Berdasarkan Tabel 3, perlakuan terbaik penambahan pisang candi adalah fruit leather apel dengan komposisi perlakuan $70 \%$ apel:30\% pisang. Perlakuan terbaik pada tahap ini memiliki tingkat kekerasan (hardness) $514.33 \mathrm{~g}$, kekompakan (cohesiveness) 1.741, kelengketan (adhesiveness) $0.27 \mathrm{~mJ}$, elastisitas (springiness) $2.42 \mathrm{~mm}$. Memiliki rasa manis kuat, sedikit rasa asam, sedikit rasa pahit, aroma apel yang kuat, sedikit aroma pisang, sedikit aroma manis, tekstur yang keras dan lengket, sedikit elastis, serta warna kuning yang kuat dan sedikit warna coklat.

\section{SIMPULAN}

Hasil analisa fisikokimia dan sensoris menunjukkan bahwa penambahan pisang candi dalam pembuatan fruit leather apel terbaik adalah sebesar 30\% yaitu dengan komposisi $70 \%$ apel:30\% pisang. Hasil sensoris dengan metode Rate All That Apply (RATA), panelis dapat merasakan 9 atribut dari 11 atribut yang ada pada fruit leather.

\section{DAFTAR PUSTAKA}

Aguilera, J,-M., 2003. Drying and dried products under the microscope. Food Sci. Technol. Int. 9, 137-143. https://doi. org/10.1177/1082013203034640

Amaliya, R,-R., Putri, W, D, -R., 2014. Karakteristik edible film dari pati jagung dengan penambahan filtrat kunyit putih sebagai antibakteri. JPA. 2, 43-53

Anggraini, S,-R., 2016. Pengaruh penambahan labu kuning dan karagenan terhadap hasil jadi fruit leather nanas. Jurnal Tata Boga. 5, 89-98. http://jurnalmahasiswa.unesa.ac.id/index.php/jurnal-tata-boga/article/view/13755

Ares, -G., Bruzzone, -F., Vidal, -L., Cadena, R, -S., Giménez, -A., Pineau, -B., Hunter, D, -C., Paisley, A, -G., Jaeger, S, -R., 2014. Evaluation of a rating-based variant of check-all-that-apply ques- 
tions: rate-all-that-apply (RATA). Food Qual. Prefer. 36, 87-95. https://doi. org/10.1016/j.foodqual.2014.03.006

Amani, N, -G., Sahore, D, -A., Kamenan, -A., 2007. Functional properties of wild yam (Dioscorea sp.) starches. Tropical Science. 47(1), 33-37. DOI: 10.1002/ts.189

Asgar, -A., Musaddad, -D., 2006. Optimalisasi cara, suhu, dan lama blansing sebelum pengeringan kubis. Jurnal Hortikultura. 16, 349-355. http://dx.doi. org/10.21082/jhort.v16n4.2006.p\%25p

AOAC, 2005. Official Method of Analysis of The Association of Official Analitycal of Chemist. The Association of Analitycal Chemist Inc, USA

Azhar, L, M, -F., Fibrianto, -K., Widyotomo, -S., Harijono., 2018. Pengaruh asal bahan baku biji kakao (Theobroma Cacao L.) dan lama conching Terhadap karakteristik tekstur dan sifat sensori dark chocolate. Jurnal Teknologi Pertanian. 19(1), 1-14

Bertuzzi, M, -A., Gottifredi, J, -C., Armada, -M., 2012. Mechanical properties of a high amylose content corn starch based film, gelatinized at low temperature. Braz. J. Food Technol. 15, 219-227. http:/ / dx.doi.org/10.1590/S198167232012005000015

Cardarelli, H, -R., Aragon-Alegro, L, -C., Alegro, J, H, -A., de Castro, I, -A., Saad, S, M, -I., 2008. Effect of inulin and Lactobacillus paracasei on sensory and instrumental texture properties of functional chocolate mousse. J. Sci. Food Agric. 88, 13181324. https://doi.org/10.1002/jsfa.3208

Diamante, L, -M., Bai,-X., Busch, -J., 2014. Fruit leathers: method of preparation and effect of different conditions on qualities. Int. J. Food Sci. 2014, 1-12. http:/ / dx.doi.org/10.1155/2014/139890

Erawati, F., 2009. Ekstraksi dan Karakterisasi Pektin Kulit Pisang (Kajian Jenis Asam Pelarut dan Rasio Bahan:Pelarut Asam). Skripsi. Universitas Brawijaya, Malang

Fauziah, -E., Widowati, -E., Atmaka, -W., 2015. Kajian karakteristik sensoris dan fisikokimia fruit leather pisang tanduk (Musa corniculata) dengan penambahan berbagai konsentrasi karagenan. Jurnal Aplikasi Teknologi Pangan. 4, 11-16

Gardjito, M., Sari, T, F, K., 2005. Pengaruh penambahan asam Sitrat dalam pembuatan manisan kering labu kuning (Cucurbita Maxima) terhadap sifat-sifat produknya. Skripsi. Universitas Gadjah Mada, Yogyakarta

Hastuti, B., 2016. Pektin dan modifikasinya untuk meningkatkan karakteristik sebagai adsorben. Dipresentasikan di Seminar Nasional Kimia dan Pendidikan Kimia VIII, Universitas Sebelas Maret, Surakarta, p. 157. http://snkpk.fkip.uns.ac.id/ wp-content/uploads / 2016/11/ BUDI-HASTUTI-PEKTIN-DANMODIFIKASINYA-UNTUK-MENINGKATKAN-KARAKTERISTIK-SEBAGAI-ADSORBEN-1.pdf

Historiasih, R., 2010. Pembuatan Fruit Leather Sirsak-Rosella. Skripsi. UPN Veteran. Surabaya

Ismail, N, S, -M., Ramli, -N., Mohd, -N., Hani, Meon, -Z., 2012. Extraction and characterization of pectin from dragon fruit (hylocereus polyrhizus) using various extraction conditions. Sains Malaysiana. 41, 41-45

Kurniasari, A, -I., Murtini, E, -S., 2017. Inovasi produk citrus infused honey tea dengan penambahan rosela (Hibiscus Sabdariffa Linn.) (kajian konsentrasi rosela dan lama infusing). Jurnal Teknologi Pertanian. 18, 21-32

Leiva Díaz, -E., Giannuzzi, -L., Giner, S, -A., 2009. Apple pectic gel produced by dehydration. Food Bioprocess Technol. 2, 194-207. https://doi.org/10.1007/ s11947-007-0035-9

Nurminah, M., Astuti, W, F, P., Nainggolan, R, J., 2016. Pengaruh Jenis Zat Penstabil dan Konsentrasi Zat Penstabil Terhadap Mutu Fruit Leather Campuran Jambu Biji Merah dan Sirsak. Skripsi. Universitas Sebelas Maret, Surakarta

Offia-Olua, B, -I., Ekwunife, O, -A., 2015. Production and evaluation of the physico-chemical and sensory qualities of mixed fruit leather and cakes produced from apple (Musa Pumila), banana (Musa Sapientum), pineapple (Ananas Comosus). Niger. Food J. 33, 22-28. https://doi.org/10.1016/j.nifoj.2015.04.004

Pradana, G, -W., Jacoeb, A, -M., Suwandi, -R., 2017. Karakter tepung pati dan pektin buah pedada serta aplikasinya sebagai bahan baku pembuatan edible film. JPHPI. 20(3), 609-619. http://journal. ipb.ac.id/index.php/jphpi/article/ viewFile/19818/13685 
Rahmanto, S, -A., Parnanto, N, H, -R., Nursiwi, -A., 2014. Penambahan gum arab menggunakan metode accelerated shelf life test (ASLT) model arrhenius. Jurnal Teknosains Pangan. 3, 35-45. https:// jurnal.uns.ac.id/teknosains-pangan/ article/view/4660

Ramadhan, -K., Atmaka, -W., Widowati, -E., 2015. Kajian pengaruh variasi penambahan xanthan gum terhadap sifat fisik dan kimia serta organoleptik fruit leather kulit buah naga daging super merah (hylocereus costaricensis). Jurnal Teknologi Hasil Pertanian. 8(2), 115-122. https://jurnal.uns.ac.id/ilmupangan/article/view/12902/10968

Risti, A, -P., Herawati, -N., 2017. Pembuatan fruit leather dari campuran buah sirsak (Annoma muricata L.) dan buah melon (Cucumis melo L.). Jurnal Online Mahasiswa Fakultas Pertanian. 4, 1-15. https://jom.unri.ac.id/index.php/ JOMFAPERTA/article/view/17050

Sa'adah, L, I, -N., Estiasih, -T., 2015. Karakterisasi minuman sari apel produksi skala mikro dan kecil di kota batu: kajian pustaka. Jurnal Pangan dan Agroindustri. 3, 374-380. http://jpa.ub.ac.id/ index.php/jpa/article/view/153

Sinurat, -E., Murniyati, 2014. Pengaruh waktu dan suhu pengeringan terhadap kualitas permen jeli. Jurnal Pascapanen dan Bioteknologi Kelautan dan Perikanan. 9, 133-142. http://dx.doi.org/10.15578/ jpbkp.v9i2.106

Sudarmadji, S., Haryono, B, Suhardi, 2010. Prosedur Analisa untuk Bahan Makanan dan Pertanian. Liberty, Yogyakarta

Tethool, E., 2011. Pengaruh Heat Moisture Treatment, Penambahan Gliserol Monostearat Serta Rasio Campuran Tepung Singkong dan Pati Sagu Terhadap Sifat Fisikokimia Sohun. Tesis. Universitas Gajah Mada, Yogyakarta
Torley, P, -J., de Boer, -J., Bhandari, B, -R., Kasapis, -S., Shrinivas, -P., Jiang, -B., 2008. Application of the synthetic polymer approach to the glass transition of fruit leathers. J. Food Eng. 86, 243-250. https://doi.org/10.1016/j. jfoodeng.2007.10.008

Torres, C, -A., Romero, L, -A., Diaz, R, -I., 2015. Quality and sensory attributes of apple and quince leathers made without preservatives and with enhanced antioxidant activity. LWT - Food Sci. Technol. 62, 996-1003. https://doi. org/10.1016/j.lwt.2015.01.056

USDA, 2017. Apples, raw, without skin. Dilihat 11 Januari 2017. < https:/ / ndb.nal. usda.gov/ndb/foods/show/2123?fgc $\mathrm{d}=$ \&man $=\& l$ facet $=$ \&count $=\& \max =\& \mathrm{~s}$ ort $=$ \&qlookup $=$ \&offset $=$ \&format $=$ Full \&new $=\&$ measureby $>$

Valenzuela, -C., Aguilera, J, -M., 2015. Effects of different factors on stickiness of apple leathers. J. Food Eng. 149, 51-60. https:/ / doi.org/10.1016/j.jfoodeng.2014.09.029

Widjanarko, S, B., 2018. Gelatinisasi pati/ adonan berbasis pati. Dilihat 5 Oktober 2018. <https:/ / simonbwidjanarko. wordpress.com/2008/06/20/gelatinisasi-pati-adonan-berbasis-pati/>

Widyaningsih, -S., Kartika, -D., Yuni, T, -N., 2012. Pengaruh penambahan sorbitol dan kalsium karbonat terhadap karakteristik dan sifat biodegradasi film dari pati kulit pisang. Molekul. 7(1), 69. http:// dx.doi.org/10.20884/1.jm.2012.7.1.108

Winarno, F., 2008. Kimia Pangan dan Gizi. Gramedia Pustaka Utama, Jakarta

Zeleny, M., 1982. Multiple Criteria Decision Making. McGraw Hill Book Company, New York

Zulkipli, F, M, P., 2016. Penambahan Konsentrasi Bahan Penstabil dan Gula Terhadap Karakteristik Fruit Leather Murbei (Morus nigra). Skripsi. Universitas Pasundan, Bandung 